\title{
Absent triceps reflex with forearm flexion
}

\section{A new form of inverted reflex}

Joumana Freiha, MD, Madiha M. Shatila, MB BCh BAO, Kamal Tarabine, MD, Naji Riachi, MD, Raghid Kikano, MD, and Rechdi Ahdab, MD, PhD

Neurology ${ }^{\circledR}$ 2020;95:314-315. doi:10.1212/WNL.0000000000010182

Figure Cervical spine MRI
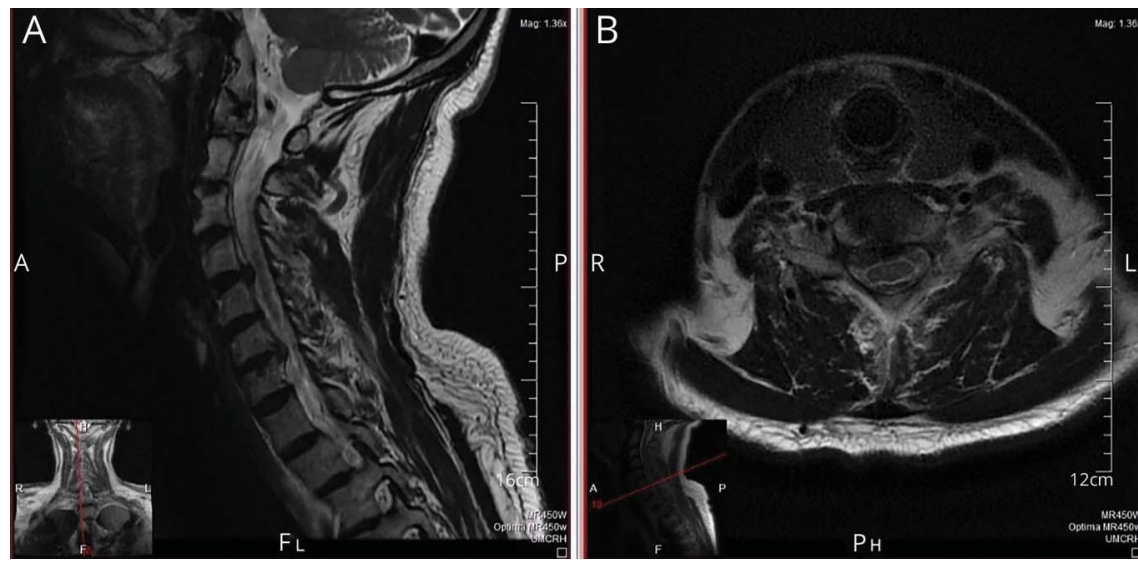

Sagittal (A) and axial (B) T2-weighted imaging of the cervical spine demonstrating protruded discs at C4-C5 and C6-C7 narrowing the spinal canal (sagittal) and right foraminal disc protrusion impinging the $\mathrm{C} 7$ nerve exit (axial).

A 65-year-old man presented with neck pain and right arm weakness and tingling. Examination displayed grade $3 / 5$ weakness of the right triceps and a C7 dermatome sensory loss. Triceps reflex testing elicited flexion rather than extension of the forearm (video 1). MRI demonstrated a large C6-C7 disc indenting on the thecal sac anteriorly and compressing the $\mathrm{C} 7$ root on the right side (figure). Spreading of the reflex to an adjacent myotome is a sign of cord injury with pathologic sensitization of the intrinsic cord circuitry. Inverted reflexes were also described in the knee ${ }^{1}$ and brachioradialis. ${ }^{2}$

\section{Study funding}

No targeted funding reported.

\section{Disclosure}

The authors report no disclosures relevant to the manuscript. Go to Neurology.org/ $\mathrm{N}$ for full disclosures.

\section{References}

1. Boyle RS, Shakir RA, Weir AI, et al. Inverted knee jerk: a neglected localising sign in spinal cord disease. J Neurol Neurosurg Psychiatry 1979;42:1005-1007.

2. Estanol BV, Marin OS. Mechanism of the inverted supinator reflex: a clinical and neurophysiological study. J Neurol Neurosurg Psychiatry 1976;39:905-908.

\section{Correspondence}

Dr. Ahdab

Rechdi.ahdab@lau.edu.lb
MORE ONLINE

- Video

From the Departments of Neurology (J.F., M.M.S., N.R., R.A.) and Radiology (K.T., R.K.), Lebanese American University, Beirut, Lebanon. Go to Neurology.org/N for full disclosures. 
Appendix Authors

\begin{tabular}{|c|c|c|}
\hline Author & Location & Contribution \\
\hline $\begin{array}{l}\text { Joumana } \\
\text { Freiha, MD }\end{array}$ & $\begin{array}{l}\text { Neurology Department, } \\
\text { Lebanese American University } \\
\text { Medical Center, Beirut }\end{array}$ & $\begin{array}{l}\text { Draft of manuscript } \\
\text { and clinical care of the } \\
\text { patient }\end{array}$ \\
\hline $\begin{array}{l}\text { Madiha } \\
\text { Chatila, MB } \\
\text { BCh BAO }\end{array}$ & $\begin{array}{l}\text { Neurology Department, } \\
\text { Lebanese American University } \\
\text { Medical Center, Beirut }\end{array}$ & $\begin{array}{l}\text { Draft of manuscript } \\
\text { and clinical care of the } \\
\text { patient }\end{array}$ \\
\hline $\begin{array}{l}\text { Kamal } \\
\text { Tarabini, } \\
\text { MD }\end{array}$ & $\begin{array}{l}\text { Radiology Department, } \\
\text { Lebanese American University } \\
\text { Medical Center, Beirut }\end{array}$ & $\begin{array}{l}\text { Analyzed and } \\
\text { interpreted the MRI } \\
\text { findings }\end{array}$ \\
\hline $\begin{array}{l}\text { Naji Riachi, } \\
\text { MD }\end{array}$ & $\begin{array}{l}\text { Neurology Department, } \\
\text { Lebanese American University } \\
\text { Medical Center, Beirut }\end{array}$ & Revision of manuscript \\
\hline $\begin{array}{l}\text { Raghid } \\
\text { Kikano, MD }\end{array}$ & $\begin{array}{l}\text { Radiology Department, } \\
\text { Lebanese American University } \\
\text { Medical Center, Beirut }\end{array}$ & $\begin{array}{l}\text { Analyzed and } \\
\text { interpreted the MRI } \\
\text { findings }\end{array}$ \\
\hline $\begin{array}{l}\text { Rechdi } \\
\text { Ahdab, MD, } \\
\text { PHD }\end{array}$ & $\begin{array}{l}\text { Neurology Department, } \\
\text { Lebanese American University } \\
\text { Medical Center, Beirut }\end{array}$ & $\begin{array}{l}\text { Revision of manuscript } \\
\text { and clinical care of the } \\
\text { patient }\end{array}$ \\
\hline
\end{tabular}

\section{The AAN is at Your Side}

When you're in the office, the AAN is at your side. The AAN is your \#1 resource to support you and your care team. Whether it's resources to help you and your staff provide the best care for your patients, ensure proper reimbursement, or maximize practice performance, the AAN is at your side. Access these resources today at AAN.com/view/practiceresources.

\section{Sign Up for the AAN's Axon Registry}

The AAN encourages its US members to show their interest in participating in the Axon Registry by signing up today.

Use the Axon Registry to:

- Simplify reporting requirements under MACRA's Quality Payment Program and avoid penalties while reducing your administrative burden

- Meet your MOC Part IV requirements and waive up to eight credits of Part II Self-Assessment

- Choose from 22 AAN neurology-specific quality measures that fit your practice

- Use data to understand your practice and identify where improvements can be made to patient care

- Manage your patients at a population level; look at a specific group of patients based on conditions, risk factors, demographics or outcome

- Demonstrate your value to payers when negotiating reimbursement

- Enjoy multi-year, fee-free access when you sign the agreements and integrate your EHR with the registry

Learn more at AAN.com/view/Axon and send your questions to registry@aan.com. 


\section{Neurology}

\section{Absent triceps reflex with forearm flexion: A new form of inverted reflex \\ Joumana Freiha, Madiha M. Shatila, Kamal Tarabine, et al.}

Neurology 2020;95;314-315 Published Online before print July 8, 2020

DOI 10.1212/WNL.0000000000010182

\section{This information is current as of July 8, 2020}

\section{Updated Information \& Services}

\section{References}

Subspecialty Collections

Permissions \& Licensing

Reprints including high resolution figures, can be found at: http://n.neurology.org/content/95/7/314.full

This article cites 2 articles, 2 of which you can access for free at: http://n.neurology.org/content/95/7/314.full\#ref-list-1

This article, along with others on similar topics, appears in the following collection(s):

Disc disease

http://n.neurology.org/cgi/collection/disc_disease

Information about reproducing this article in parts (figures,tables) or in its entirety can be found online at:

http://www.neurology.org/about/about_the_journal\#permissions

Information about ordering reprints can be found online:

http://n.neurology.org/subscribers/advertise

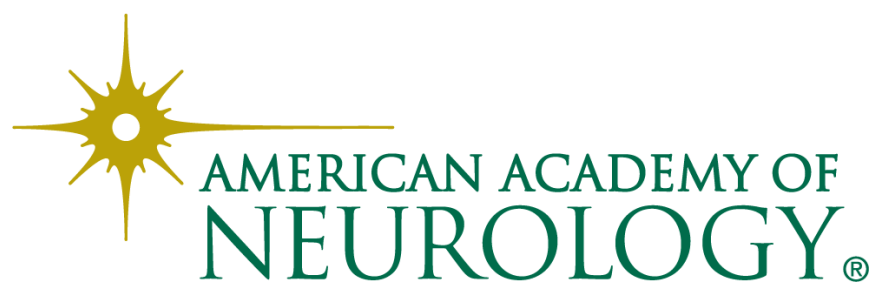

